\title{
ON THE NATURE AND EVIDENCE OF TITLE TO REALTY
}

\author{
Richard C Maclaurin*
}

After studying mathematics at Cambridge, Maclaurin turned to the study of law, partly as a result of his friendship with the South African Jan Smuts. As part of his LLM studies he wrote a thesis which was awarded the Yorke essay prize in 1898. The essay was published in 1901, making it the first legal book published by a Victoria academic, albeit a Professor of mathematics. Later Maclaurin's position as a Law Professor was formalised but like Salmond he departed, firstly for Columbia and then MIT. Legal Education's loss became Science Education's gain.

\section{INTRODUCTORY}

The advantages of studying the history of a subject need not be set out today when the triumphs of the historical method are among the commonplaces of the schools. We have all learnt in a measure that "the roots of the present lie deep in the past". Law grows with society, and if we would understand its later development we must know something of its youth. With this truth before us we cannot fail to find a living interest in much that would otherwise appear dead, and even the formalities of law are clothed with new meaning.

In many pursuits the most serious obstacles are met at the outset, and this is specially true in the study of legal history. The materials are usually most scanty where the natural difficulties are greatest, and although simplicity may be reached in the end, at the beginning we can expect only the indefinite. The one safe method seems to be to work backwards from the known to the unknown, and from a careful study of historic times to get a clue to what has gone before. For institutions do not often pass away without leaving some fossil remains that may serve to restore a bygone age. Still even with this help the task of reconstruction is far from easy, and although we may get some further guidance from a

- Professor of Mathematics, and later Professor Law, Victoria University of College. The first publication was Richard C Maclaurin, On the Nature of and Evidence of Title to Reality: a Historical Sketch (C J Clay \& Sons, London, 1901). 
survey of primitive societies that still exist we cannot always rely on this, for we have no right to assume that the order of progress has been everywhere the same.

Our object in the present essay is to consider the various modes of acquiring real property that have obtained through English history. Men have not always had private property in land, and the first question to discuss is - when did our forefathers begin this practice and what were their methods of acquiring such property? The problem of the origin of property has been discussed for ages. The Roman jurists had much to say about the "natural" modes of acquisition, chief among which was Occupancy, "the advisedly taking possession of what at the moment is the property of nobody, with the view of acquiring property in it for oneself". In this process was seen the first step towards private ownership, and the theory was accepted with satisfaction by successive jurists and popularised in England by Blackstone. ${ }^{1}$

"The earth and all things therein were the general property of mankind from the immediate gift of the Creator ... By the law of nature and reason he who first began to use it acquired therein a kind of transient property that lasted so long as he was using it and no longer ... Thus the ground was in common and no part was the permanent property of any man in particular; yet whoever was in the occupation of any determined spot of it, for rest, for shade, or the like, acquired a sort of ownership from which it would have been unjust and contrary to the law of nature to have driven him by force, but the instant that he quitted the use or occupation of it another might seize it without injustice ... When mankind increased in number it became necessary to entertain conceptions of more permanent dominion and to appropriate to individuals not the immediate use only, but the very substance of the thing to be used."

There is, no doubt, an element of truth in what Blackstone says, but very little examination will show that his statement is a poor explanation of the origin of private property. Blackstone pictures us a man in the early stages of society acquiring a sort of ownership "from which it would have been unjust and contrary to the laws of nature to have driven him by force." We are not acquainted with any "law of nature" 2 that has a bearing on the matter; and as to its "injustice" we might be agreed today, but the natural man in the earliest ages may not have had so much respect for what we call justice. In fact the whole theory clearly presupposes a somewhat advanced conception of justice and morality

1 Blackstone, Comm II 3.

2 The phrase is a very ancient one and covers a multitude of obscurities. Doubtless Blackstone here uses it for the precept of reason to refrain from molesting others with a view to self-preservation. Hobbes (Leviathan, I. c. 15) enumerates nineteen "laws of nature" and adds "These have been contracted into one easie sum intelligible even to the meanest capacity, Do not that to another which thou wouldest not have done to thy selfe" - a negative statement of the Golden Rule. 
on the part of the community, and although it may explain the function of "occupancy" at a later period of history it can help us little at the beginning.

We shall examine the light that history throws on the subject a little later; but since the historical accounts leave much to be desired it may be well to see what help can be got from a study of existing primitive races. For this purpose we may arrange these races under a number of types. The lowest-represented by the Bushman of South Africa, or some of the inhabitants of central Borneo - consists of a primitive horde of wandering hunters, with neither houses nor cattle. They have not even regular hunting grounds (being in this matter less advanced than many animals); they own only what they actually hold.

A slightly higher type is met with in Australia and other places where a clan system prevails. The members of the clan are, or are supposed to be, akin. They have advanced from the lowest type insofar as they have a well defined hunting ground; but this belongs to the clan and not to the individual. However, already we see the elements of private property, though not in land. A few things are appropriated to individuals, the most important being ornaments and weapons. What induced the strong man to leave the weaker in undisturbed possession of such objects is not so easily settled. It is a question of fundamental importance if we are to explain the origin of private property; but as with many fundamental questions we have little data to help us to a decision and must leave the subject to those with a taste for controversy.

The next type is represented by tribes from North American Indians or the Maories of New Zealand. There is now a considerable amount of private property in goods - in food, weapons, canoes and most important of all in slaves. Agriculture is beginning to receive attention, although it is yet very primitive. The same patch of ground is seldom cultivated continuously, but after one piece has been exhausted a move is made to another. The results are not very satisfactory and consequently agriculture is looked upon with a certain measure of indifference and contempt. It is fit only for women and slaves; the serious and dignified business of life - hunting and war - is left for the free man. Such as it is however, agriculture is already a source of wealth and its importance grows with the institution of slavery. Slaves are obtained by fighting, and as their usefulness increases the rewards of the successful warrior are magnified. Wealth accumulates and leads to distinctions of rank and power, and ere long chiefs begin to demand special privileges and do much to develop the idea of private ownership even in land.

The next stage is reached when we come to the village community, a type that has received special attention from a number of jurists ${ }^{3}$ who have discussed it as it exists in

3 Von Maurer, Nasse, Maine, Haxthausen, Tengoborski, Vinogradoff, Seebohm, Gomme, and others. 
India and Russia today as well as in Britain and other parts of western Europe in the past. Each tribe is divided into a number of smaller groups bound together by ties of kinship, real or imagined. Agriculture has now become "intensive" the great discovery having been made that by proper treatment the same piece of ground may be cultivated from year to year. The arable land is distributed among the different families, often by lot, but the pastures are held in common by the clan. The chief has increased his privileges since the last stage; his land has been in many cases become hereditary, and as a rule he claims large powers over all the territory that has not been allotted.

As time goes on the powers of the chief increase, and to meet his growing demands the claims of the kindred and the clan have to be set aside. The idea of private ownership in land thus fostered by the head of the state is disseminated by many forces - notably by the church in Western Europe - until at length our present stage is reached when private property seems simple and "natural" and we have a difficulty in believing that any other system could ever have prevailed.

Where in this scheme are we to place the Anglo-Saxons just before their descents on England? The question cannot be answered with certainty, but the evidence we have tends to show that they were in the stage of transition preceding that of village communities. As far as land laws were concerned their state was like that of the Maories or Red Indians. On this subject the sources of information from the side of history are two - the writings of Caesar and of Tacitus. Caesar gives us two descriptions, one of the Germans generally, the other of a particular tribe, the Suevi. Speaking of the Germans as a whole he says that no one has a fixed quantity of land, but that each year portions are assigned by the chiefs to groups of families united by ties of kinship. The group occupies the land for a year and is then moved elsewhere. So too of the Suevi "Privati ac separati agri apud eos nihil est, neque longius anno remanere uno in loco incolendi causa licet." ${ }^{4}$ About a century and a half later Tacitus writes with fuller knowledge. We cannot be sure that he is describing the same tribes as Caesar; but, if so, there has been a marked advance. The old wandering life has been given up and the tribe settled down in permanent villages. The arable land is changed from year to year, being allotted among the different members of the community in accordance with their rank. ${ }^{5}$

Agri pro numero cultorum ab universis in vices occupantur, quos mox inter se secundum dignationem partiuntur ... Arva per annos mutant.

4 Caesar, de Bello Gallico, iv 1.

5 Tacitus, Germ c xxvi. The text is doubtful. Some read vicis. 
It must not be thought, however, that private property in land is unknown. There is a distinct touch of individualism, for each man has a homestead of his own which is clearly marked off from that of his neighbours. ${ }^{6}$

Colunt discreti ac diversi ... Vicos locant non in nostrum morem conexis et cohaerentibus aedificiis; suam quisque domum spatio circumdat.

This is practically all we know from history of the land system of these early days. Several centuries elapsed from the time of Tacitus until the Saxons began their invations of Britain. What happened in the meantime can only be conjectured, and indeed, as we shall see in the next chapter, it is long after the invasions were at an end before we have anything very definite on which to go. When, however, we do come again into the clear light of history we find much to suggest that the methods of which Tacitus wrote were employed by the invaders, the most abiding witness being the open field system of agriculture of which there are many traces even today."7

6 Tacitus, Germ c xvi.

7 See Seebohm, English Village Communities; Gomme, The Village Community. 
